\title{
Linguistic transfer in English as a foreign language in a single free writing task in Polish students with and without dyslexia
}

\author{
Marta Łockiewicz*, Martyna Jaskulska** \\ *University of Gdańsk; marta.lockiewicz@ug.edu.pl \\ **Derdowski High School in Kartuzy; mal.jaskulska@gmail.com
}

\begin{abstract}
The aim of our study was to examine the spelling, grammar, syntax, and lexicon skills in learning English as a Foreign Language (EFL) in a free writing task of Polish students with and without dyslexia. We wanted to identify the potential linguistic transfer difficulties. We assumed that these difficulties would result from the deficient phonological skills, which is characteristic of dyslexia, and from language interference. 72 students with and 78 without dyslexia wrote a short text in English. We found that Polish secondary and junior secondary school students with dyslexia, as compared to the participants without dyslexia, made more spelling errors in the EFL free writing task. They, however, wrote equally long texts that did not differ in terms of grammar (including missing words), syntactic, and lexical errors. We found that 16-year-old native speakers of a semi-transparent Polish, having studied an opaque English for, on average, 8 years, were able to produce coherent compositions. However, they included errors that resulted from a negative linguistic transfer between Native Language and FL.
\end{abstract}

Keywords: English as FL, free writing, spelling, grammar, dyslexia, Polish

\section{Introduction}

Behavioural symptoms characteristic of dyslexia, a specific learning disability, include difficulties in word recognition and decoding (which is not fluent and/or accurate) and in spelling (Lyon Reid, Shaywitz and Shaywitz 2003: 1-14). A secondary disturbance, poor reading comprehension, may lead to limited general knowledge and vocabulary. These difficulties, studied extensively in NL (Native Language), result from cognitive deficits, which include impaired: phonological awareness, verbal working memory, rapid automatized naming (RAN), access to mental lexicon, and pace of information processing (Crombie 2000: 112-123, Krasowicz-Kupis 2008: 151-153). Literacy problems are also expected in FL (Foreign Language), as phonological skills in NL influence FL reading and spelling proficiency (linguistic transfer) (Geva \& Verhoeven 2000: 261-266). Literacy learning in both NL and FL likely depends on comparable language learning mechanisms, as the same cognitive skills: phoneme awareness, letter-sound knowledge, and RAN in emergent readers predict reading development in alphabetic orthographies of a diverse level of transparency: English, Spanish, and Czech (Caravolas, Lervåg, Defior, Málková \& Hulme 2013: 1398-1407). Cummins (1979) proposed in the linguistic interdependence theory that the competence already achieved in NL influences the subsequent development of FL competence. Thus, learners exhibit comparable semantic, syntactic or phonological aptitudes and/or difficulties in all languages they study, as the Linguistic Coding Differences Hypothesis (LCDH) states (Sparks, Patton, Ganschow \& Humbach 2009: 203-243, Sparks, Patton, Ganschow, Humbach \& Javorsky 2006: 129-160). $\mathrm{NL}$ skills differences between more and less successful learners appear early in elementary school and are related to FL proficiency and achievement in high school, which provides evidence for a long-term cross-linguistic transfer (Sparks, Patton, Ganschow \& Humbach 2009: 203-243). A cross-linguistic skill transfer was confirmed between, among others: Chinese and English (Chung \& Ho 2010: 195-211), Hungarian and Romanian (Gál \& Orbán 2013: 173-193), Italian and English (Palladino, Bellagamba, Ferrari \& Cornoldi 2013: 165-177), Urdu and English (Farukh \& Vulchanova 2016: 221-233), Polish and English (Łockiewicz \& Jaskulska 2016, Nijakowska 2010), and Dutch and English (van Sette et al. 2017).

Language interference also constitutes a problem for the speed and accuracy of FL learning and is discussed in terms of a negative linguistic transfer (Odlin 1989, Zybert 1999), and a positive one (Zybert 1999). Such a situation occurs when learners apply their NL rules to FL production, which may lead to transfer errors, especially if the languages are dissimilar (Zybert 1999). In fact, when learning a foreign language, a common linguistic system is created, as L1 and L2 interact with one another to facilitate comprehension and production (Wodniecka, Mieszkowska, Durlik \& Haman 2018: 92-131). Arabski (1968: 71-89) states that in the case of English-Polish pair of languages, the linguistic interference 
includes: external active (negative transfer: using NL structures and habits), external passive (confusing categories non-existent or differently constructed in NL), and internal (analogy: incorrect use of FL rules) interference. In this study we wanted to investigate linguistic transfer in the spelling, grammar, syntax, and lexicon skills in the free writing task between Polish as NL and English as a Foreign Language (EFL). Poland is a monolingual country, in which $94.8 \%$ of the population claim to be of exclusively Polish nationality, and only $1.55 \%$ indicate national or ethnic identity other than Polish (Główny Urząd Statystyczny 2015: 29). English instruction formally begins in the Reception Year (entered usually at 6 yrs.), though kindergartens also offer English courses. 98\% of students study it in secondary school, and the majority of them choose it as one of the obligatory subjects to be tested at the 'matura' exam, an obligatory external exam after secondary school graduation (www.cke.edu.pl). Exposure to English of Polish learners is then limited to school and media (e.g. the Internet, and/or television). This is not an immersion context, as students are taught English only during EFL class, and they are instructed in Polish when they attend all other classes. Moreover, EFL learners in Poland have limited opportunities to communicate in English in everyday life, as they usually have no contact with native speakers outside of school.

Differences between an analytical opaque English, and a synthetic inflectional semi-transparent Polish include, respectively: more fixed (order of words indicates a word syntactic function) vs. flexible (suffixes and inflections: declension and conjugation indicate a word syntactic function) SVO pattern, no double negation vs. multiple negation, articles vs. no articles, inversion vs. no inversion in questions (cf. Dansk \& Kurcz 1984: 245-269, Fromkin, Rodman \& Hyams 2011, Milewski 2006). English phonology is transcribed with the International Phonetic Alphabet, whereas Polish also with the Slavonic Phonetic Alphabet (Ryndak 2014: 83-89). Both languages include phonemes not present in the other repertoire. Therefore, Polish learners of English encounter difficulties stemming from phonetic/phonological, orthographic, grammatical, syntactical, lexical differences between NL and FL. Moreover, in less consistent languages, to which English belongs, it takes longer to learn to read (Caravolas et al. 2013: 1398-1407) and write (Caravolas and Volín 2001: 229-245), as compared with more consistent languages, to which Polish belongs.

The aim of our study was to examine the spelling, grammar, syntax, and lexicon skills in learning EFL in the free writing task of Polish students with and without dyslexia. We wanted to identify the potential linguistic transfer difficulties in the students' writings. We assumed that these difficulties would be connected to the deficient phonological skills, which is characteristic of dyslexia (the better the phonological skills in $\mathrm{NL}$, the better the phonological skills in $\mathrm{FL}$ ), and language interference (overgeneralization of NL spelling, grammar, syntax, and vocabulary rules and their usage in FL production). We expected a negative transfer in both cases, as dyslexia stems from a phonological deficit, and semi-transparent synthetic Polish and opaque analytical English differ substantially. This research is a part of a larger project that aims to investigate the problems of Polish children with and without dyslexia in learning NL and FL. We assumed that Polish students with dyslexia, as compared with Polish students without dyslexia, would make more spelling errors in the free writing task. Poor spelling in English as FL has been reported in Norwegian (Helland \& Kaasa 2005: 41-60) and Swedish and Finnish (Lindgren \& Laine 2011: 753-766) learners with dyslexia. An earlier study (Łockiewicz \& Jaskulska 2016) demonstrated poorer spelling in dyslexia of single, unrelated English words dictated to native speakers of Polish. These words were selected specifically to include phonological structures challenging for learners with specific difficulties in reading and writing. In the free writing task used in the present study, the students themselves chose vocabulary and phrases to use. Moreover, in such a task we could examine not only spelling, but also grammar, lexical, syntactic errors, and the length of the text, which allowed us to more fully describe the EFL writing in dyslexia. We found no other study that would compare these features of a written text in FL of Polish students with dyslexia learning EFL. Difficulties in FL learning are only mentioned as, for example, reported by teachers or parents (Bogdanowicz 2011). In an earlier study by Jurek (2004: 98-116) Polish adolescents with dyslexia, as compared with their peers without dyslexia, self-reported bigger difficulties in spelling, but also grammar and the ability to create a text in foreign languages that they studied, mostly English (90\%) and German (30\%) - both orthographies 
having a different degree of transparency. We wanted to investigate these self-assessments through the examination of the actual spelling, grammar, syntactic, and lexicon skills of EFL in Polish learners.

\section{Materials and methods \\ Methods}

The following methods were used in the research:

Questionnaire - completed by the parents and students, informing about: demographic data, English education and exposure, dyslexia report.

Test Matrices. Standard version by Raven (1991), a Polish adaptation, assessing nonverbal intelligence. This task was used to match the criterion and the control group for the intelligence level.

Polish single words reading task by Krasowicz-Kupis (Jaworowska, Matczak \& Stańczak 2010), measuring the accuracy and fluency of decoding 89 unrelated words. This task, standardised and normalised for Polish speakers, was used to confirm reading deficits in NL in the criterion group.

The free writing task - measuring spelling (i.e. the number of spelling errors) and writing (i.e. the number of grammar, syntactic, and lexical errors) accuracy in FL (English). The students were given an A4 sized blank piece of paper, with the beginning of the expected composition printed at the top of the page: For the next holiday, I would like to go to... The participants were then instructed to finish the sentence, and then further elaborate on the topic, within the time limit of 5 minutes. We used a simple topic that required no specific knowledge and was pleasant to write about, as the task was performed in FL. Since we were interested in the words and sentences accuracy, not in the content and ideas, there was no time given for preparation (e.g. planning, note-taking). The participants performed the task without stopping, and no time was provided for revision, editing, and self-correction after writing. However, the participants could have corrected themselves when writing. The compositions were handwritten.

We assessed the following categories of errors: spelling (orthographic or phonological mistakes), grammar (a breach of grammatical rules), syntactic (applying typically Polish rules of syntax, e.g. implied subject; not following SVO pattern), lexical (wrong collocations; false friends). Moreover, within the grammar category, we differentiated a subcategory of missing words, the omission of which resulted in faulty grammar. The length of the text was measured with the number of words, not sentences, as an earlier study demonstrated that Polish students with dyslexia failed to use punctuation correctly in NL when writing an essay (Makarewicz 2007: 109-125). Polish single word reading task was administered individually; the participants completed all the other tasks during a group session.

\section{Participants ${ }^{26}$}

$72(48 \%)$ secondary and junior secondary school students with and $78(52 \%)$ without dyslexia, all native speakers of Polish, participated in the research. Dyslexia was confirmed by a legally valid, independent psychological report following the ICD-10 (2000: 201-207), and including: IQ over 85, achievement test scores for reading and spelling below the -1 SD cut-off (decoding, text reading, reading comprehension, writing), processing deficit symptoms including phonological skills, assessed with standardized testing measures. Moreover, dyslexia group read single actual Polish words less accurately ( $M d n=81$ for the criterion group, $M d n=87$ for the control group, $U=1055, Z=6.61, p \leq .001, r=0.54$ ) and more slowly than the control group ( $M d n=82$ for the criterion group, $M d n=60$ for the control group, $U=1173, Z=6.15, p \leq .001, r=0.50)$. The groups were matched for: gender $\left(\chi^{2}(1)=2.26, p=\right.$ $.136)$, age $\left(M_{\text {age }}=16.23\right.$ yrs., $S D_{\text {age }}=19.02$ months, $\left.t(147)=0.125, p=.900\right)$, IQ $(t(148)=0.54, p=.588)$, English instruction ( $M=8$ yrs., $S D=1.95$ yrs., $t(133.58)=0.26, p=.799)$. The results of 2 students were excluded, as they had spent more than 6 months living in a foreign country, and of 6 due to the IQ level below average. All the students and their parents expressed informed consent for the children to participate in the study.

\footnotetext{
${ }^{26}$ The present study combines evidence from the two databases (for high and junior high school students) used in Łockiewicz andJaskulska (2019, 2018, 2016, 2015).
} 


\section{Results}

\section{Quantitative analysis}

The Mann-Whitney test for independent samples (Table 1) showed that participants with dyslexia, as compared to the participants without dyslexia, made more spelling errors in the free writing task (Mdn = 3.00 for the criterion group, $\mathrm{Mdn}=2.00$ for the control group, $U=1786.00, Z=3.78, p \leq .001, r=0.31$ ), but an equal number of the following errors: grammar ( $\mathrm{Mdn}=5.00$ for both the criterion and the control group, $U=2651.50, Z=0.45, p=.654, r=0.04$ ), including missing words ( $\mathrm{Mdn}=2.00$ for both the criterion and the control group, $U=2540.50, Z=0.883, p=.377, r=0.07$ ), syntactic (Mdn $=0.00$ for both the criterion and the control group, $U=2440.00, Z=1.68, p=.093, r=0.14$ ), and lexical (Mdn = 0.00 for both the criterion and the control group, $U=2765.5, Z=0.19, p=.985, r=0.02$ ). In total, students with dyslexia spelt $92 \%$ of words in their texts correctly, while their normally reading peers: $96 \%$. The texts did not differ in length, as measured with the number of words written (Mdn $=48$ for the criterion group, $\mathrm{Mdn}=53.5$ for the control group, $U=2259, Z=1.68, p=.094, r=0.14)$.

Table 1: Descriptive characteristic of the compared groups: spelling, grammar, syntax, and lexicon skills in English as Foreign Language of Polish students - the free writing task.

\begin{tabular}{|c|c|c|c|}
\hline & dyslexic & non-dyslexic & \\
\hline & $M d n$ & $M d n$ & \\
\hline number of words & 48.00 & 53.50 & $U=2259.00, Z=1.68, p=.094, r=0.14$ \\
\hline spelling errors & 3.00 & 2.00 & $U=1786.00, Z=3.78, p \leq .001, r=0.31$ \\
\hline grammar errors & 5.00 & 5.00 & $U=2651.50, Z=0.45, p=.654, r=0.04$ \\
\hline missing words* & 2.00 & 2.00 & $U=2540.50, Z=.883, p=.377, r=0.07$ \\
\hline syntactic errors & 0.00 & 0.00 & $U=2440.00, Z=1.68, p=.093, r=0.14$ \\
\hline lexical errors & 0.00 & 0.00 & $U=2765.50, Z=0.19, p=.985, r=0.0$ \\
\hline
\end{tabular}

Note: median figures given.

*Missing words are a subcategory included in the category of grammar mistakes

\section{Qualitative analysis}

Below, we present examples of errors from the students' works:

(1) spelling: deletion (*galery - a silent consonant), substitution and addition (*buetifull), segmentation (*withmore), shifting (*symphatetic);

(2) grammar: incorrect tense (*I always dream about it - the context made it clear that a Present Perfect construction should have been used), incorrect gerund/infinitive (*I like to skateboarding), incorrect inflectional ending (*I want to finished), preposition (*onor at summer, ${ }^{*}$ different then the European countries), article (*the Los Angeles), suffix and/or prefix (*Warsaw is interestal/interested), copying Polish rules of concord(*these holiday - in Polish 'holiday' is always plural), keeping inversion when it should be dropped (*There are many cities, where is a beach), missing words, such as: articles (*from north of Europe, *I'd like to go to UK), subjects (*In London are some modern skateparks, *In Budapest is very hot), verbs (*I going to ride a bike, *now when crisis raging);

(3) syntactic: *I'd like to travel to Washington where lives the president, *I always was going to the beaches;

(4) lexical: word formation errors (*monasters), incorrect combinations of words in collocations (*do photos), faulty word translation, the so-called false friends (*shopping gallery-galleria handlowa, meaning a shopping mall in Polish); homophones confusions (*travel by plain, * grate country).

\section{Discussion}

The participants with dyslexia, as compared to the participants without dyslexia, made more spelling errors in the FL free writing task. This result is consistent with earlier reports of spelling difficulties of FL learners with dyslexia (Helland \& Kaasa 2005: 41-60; Łockiewicz \& Jaskulska 2016), which occur even in the free writing task (Lindgren \& Laine 2011: 753-766), when students can themselves select the vocabulary they want to use. Moreover, this finding supports the phonological deficit hypothesis of 
dyslexia (Hoien, Lundberg, Stanovich \& Bjaalid 1995: 171-188, Snowling 2000), which assumes that dyslexia is mainly caused by phonological awareness and working memory disturbances. The fact that difficulties with phoneme-to-grapheme conversion appear in FL with a different degree of transparency from NL further evidences the linguistic transfer of phonological skills (Geva \& Verhoeven 2000: 261266), and the common conditioning of NL and L2 language learning (Caravolas et al. 2013: 1398-1407). According to the Linguistic Coding Differences Hypothesis (Sparks et al. 2009: 203-243, Sparks et al. 2006: 129-160), even though students may exhibit semantic, syntactic, or phonological difficulties in more than one language (Ganschow and Sparks 2000: 87-100), deficits in the phonological code prove to yield the biggest difficulties in foreign language learning, and influence such affective factors as motivation, attitude or anxiety (Bjaalid, Hoien \& Lundberg, 1997: 73-82, Sparks \& Ganschow 1993: 5874).

We found that our participants with dyslexia, as compared with the controls, wrote equally long texts that did not differ in terms of grammar, including missing words, syntactic, and lexical errors. It seems that their FL difficulties stem from limited phonological knowledge and they express it in faulty spelling. These findings are in contradiction to Jurek's report (2004: 98-116), as her informants with dyslexia, in a self-report questionnaire, declared that they believed that their own grammar and text writing skills in FL were poorer, as compared to those of their peers without dyslexia. We assume that Polish students with dyslexia might believe that their problems in FL learning extend to all literacy aspects, which our study does not support. Such lack of skills assumptions may be detrimental for study motivation. Making errors, which is inevitable, may upset the learners and lower their self-confidence, and if persistent, even cause lack of motivation (Ellis 1985). Kormos, Kiddle and Csizér (2011: 495-516) claim that learnerinternal factors: attitudes and self-related beliefs, which are under the influence of external factors: social, cultural, and instructional setting, affect persistence and effort in second language acquisition. Consequently, students might give up studying English and lose interest in the subject. Moreover, we believe that an attitude of general lack of foreign language skills' aptitudes might be reinforced by teachers, as Polish literature reports NL problems in: compound sentences compositions, proper using of adverbs and adjectives, poor grammar with regard to concord and government, morphology and syntax awareness, and shorter essays, as characteristic, though secondary, in dyslexia (Krasowicz-Kupis 2006: 53-69, 2008: 299-314). Since literature has shown a connection between NL and FL skills (Cummins 1979, Sparks et al. 2009: 203-243, Sparks et al. 2006: 129-160), being aware of Polish students' with dyslexia NL literacy problems, the teachers might expect that they would experience also analogical problems in FL literacy, especially that publications directed at parents and teachers explicitly mention such difficulties (Bogdanowicz 2011). Therefore, we believe that our findings carry important implications for the teachers of English as a second language in Poland. The teachers should concentrate on adjusting their instruction to the specific needs of dyslexic students' problems in spelling acquisition. At the same time teachers should reinforce students' self-efficacy and self-confidence as to their FL skills at grammar, syntax, and active lexicon. Textbooks and courses designed for the teachers of English as a second language working with students with dyslexia were developed within DysTEFL and DysTEFL2 projects (Nijakowska 2016: 32-38).

Qualitative analysis of the short texts written by the students in our study shows that after on average 8 years of studying English as FL, they were able to construct a text of, on average, 50 words within 5 minutes, out of which 96\% (in the control group) and 92\% (in the dyslexia group) were correct. Thus, they fulfil the curriculum requirement of producing short, comprehensible written texts (Ellis \& Niesobska 2015). The spelling errors: deletions, substitutions, additions, incorrect segmentation, or letter shifting are characteristic of dyslexia (Mather \& Wendling 2012: 147-177). Many of the spelling, grammar, syntactic, and lexical mistakes in the works of the students in our study result from a negative linguistic transfer due to language interference (Benson 2002: 68-70, Odlin 1989, Zybert 1999). In spelling, students deleted silent letters and double consonants when only one was pronounced. The most common grammar errors comprised missing words, including: the definite and indefinite articles, subjects, and verbs. In Polish, no articles accompany nouns and personal pronouns are frequently dropped due to the fact that inflection of the verb denotes both the action itself and the action's doer (in such a situation we talk about 'the implied subject'). Tenses which are especially difficult for Polish 
students are the ones that do not appear in Polish, for example the progressive form (in Polish usually rendered by adverbial phrases), or the perfect tenses. Moreover, the English Present Perfect and Simple Past sentences may both translate to Polish identically. Other grammar errors stemmed from copying NL rules of concord and nouns countability. Moreover, the participants used typically Polish constructions of a sentence, translating Polish sentences word-for-word into English. SVO order rules in Polish are rather flexible and it is not necessary to follow the exact SVO pattern to form correct sentences. This leads to problems when students apply NL rules when writing in $\mathrm{FL}$, which results in, for example, forming questions with no inversion or keeping inversion when it should be dropped, e.g. in case of indirect questions. On the lexical level, students sometimes used calques of Polish words, assuming that if they look similar, they probably mean the same. The participants also used incorrect articles and phrasal verbs. This can be explained by the fact that the two groups of lexical items do not exist in Polish. In addition, the aforementioned errors could be classified as external active (e.g. missing subjects and verbs, copying rules of concord, nouns countability, using Polish word order in a sentence, vocabulary calques) and external passive (e.g. silent letters or double consonants deletion, missing articles, improper Present Perfect usage, no inversion, incorrect use of articles and phrasal verbs) errors according to Arabski's (1968: 71-89) classification. Thus, certain consistency in a pattern of errors can be noticed (Arabski 1968: 71-89). Kubiak (2003: 39-49) claims that in the second language acquisition the occurrence of an interlanguage, characterised by strong interference, is inevitable, and every effort must be taken not to consolidate it. In our study, examples of errors based on the negative linguistic transfer referred to problems with inflectional endings (grammar), incorrect combinations of words in collocations (lexical), and homophones confusions (lexical). These errors resulted either from a poor knowledge of FL grammar and vocabulary (a competence error), or from an incorrect application of known rules, due to, e.g. inattention or distraction (a performance error) (cf. Hoien \& Lundberg 2013). Negative linguistic transfer errors were more conspicuous. This finding carries important implications for EFL instruction. Since numerous errors committed by Polish learners of EFL result either from an unjustified application of Polish grammar rules to a work created in EFL, or a lack of sufficient knowledge of English grammar rules, as the above-listed evidence suggests, we believe that EFL instruction should include an explicit explanation of similarities and differences between NL and FL (in grammar, syntax, lexicon and phonology), with an indication which difficulties might appear, as they can be predicted on the basis of interlingual differences and the examination of typical errors committed by learners. This is especially important as EFL textbooks usually fail to include comparisons between NL and EFL (Paradowski 2006: 125-144). Thus, teachers need to adjust their teaching to the specificity of a given NL that their students use.

\section{Limitations}

The 5-minute time given to students proved enough for them to produce coherent, though short, texts that demonstrated a characteristic pattern of errors. However, the writings were quite diverse in terms of content (e.g. descriptions of locations vs. reasoning for the choice of location) and the structures used (e.g. dominant Present tense or auxiliary verb will). We would like to conduct further studies in which we would use a closed test procedure to identify the most difficult grammar, syntax, and lexical aspects of writing for Polish learners of English.

\section{Conclusions}

In our study Polish secondary school students with dyslexia, as compared to the participants without dyslexia, made more spelling errors in the FL free writing task. However, they wrote equally long texts that did not differ in terms of grammar (including missing words), syntactic, and lexical errors. These findings verify the assumptions of the LCDH and phonological deficit hypothesis. They may also help dyslexic students improve their performance, enhance their self-esteem, and prevent them from feeling excluded. Moreover, we found that 16 -year-old native speakers of a semi-transparent Polish were able to produce short and coherent texts, having studied an opaque English for 8 years. These works, however, included some errors that resulted from copying the rules of NL to FL. Thus, we confirmed the occurrence of both types of negative linguistic transfer between NL (Polish) and FL (English). Poorer 
performance of the learners with dyslexia, as compared with that of the learners without dyslexia, demonstrates the negative linguistic transfer. Copying the rules of NL to FL, when not applicable, demonstrates the negative linguistic interference.

The acquisition of English as a Foreign Language is an important part of the obligatory curriculum internationally. In Poland, it is taught from the first year of education and included in state examinations. Our results show the need for adjusting second language instruction to the differences between NL and FL to avoid or diminish characteristic mistakes that all learners are likely to make. This is consistent with Odlin's (1989) observation that specific errors are connected with specific learners' backgrounds. As certain types of errors, which we identified in our paper, are likely to appear in the works of the majority of EFL Polish learners, the teachers could prepare in advance exercises designed to promote the idea of certain grammar rules being different between Polish and English. Such exercises, when introduced early, could prevent learners from establishing and consolidating incorrect linguistic habits, and be complimentary to the content of the used textbook. Thus, they might help develop methods that would enable students to eliminate at least part of the mistakes.

\section{References}

Arabski, J. (1968). A linguistic analysis of English composition errors made by Polish students. Studia Anglica Posnaniensia: An International Review of English Studies, 1 (1-2), 71-89.

Aro, M. \& Wimmer, H. (2003). Learning to read: English in comparison to six more regular orthographies. Applied Psycholinguistics, 24 (4), 621-635.

Benson, C. (2002). Key concepts in ELT. Transfer/cross-linguistic influence. ELT Journal, 56 (1), 68-70.

Bjaalid, I., Hoien, T. \& Lundberg, I. (1997). Dual-route and connectionist models: a step towards a combined model. Scandinavian Journal of Psychology, 38 (1), 73-82.

Bogdanowicz, K. (2011). Dysleksja a nauczanie języków obcych. Przewodnik dla nauczycieli i rodziców uczniów z dysleksja [Dyslexia and teaching foreign languages. A handbook for teachers and parents of students with dyslexia]. Gdańsk: Wydawnictwo Harmonia.

Caravolas, M. \& Volín, J. (2001). Phonological spelling errors among dyslexic children learning a transparent orthography: the case of Czech. Dyslexia, 7, 229-245. https://doi.org/10.1002/dys.206.

Caravolas, M., Volin, J. \& Hulme, C. (2005). Phoneme awareness is a key component of alphabetic literacy skills in consistent and inconsistent orthographies: evidence from Czech and English children. Journal of Experimental Child Psychology, 92 (2), 107-139.

Caravolas, M., Lervåg, A., Defior, S., Seidlová Málková, G. \& Hulme, C. (2013). Different patterns, but equivalent predictors, of growth in reading in consistent and inconsistent orthographies. Psychological Science, 24 (8), 13981407.

Chung, K. K. H. \& Suk-Han Ho, C. (2010). Second language learning difficulties in Chinese children with dyslexia: what are the reading-related cognitive skills that contribute to English and Chinese word reading?. Journal of Learning Disabilities, 43 (3), 195-211.

Crombie, M. A. (2000). Dyslexia and the learning of a foreign language in school: where are we going?. Dyslexia, 6 (2), 112-123.

Cummins, J. (1979). Linguistic interdependence and the educational development of bilingual children. Review of Educational Research, 49, 222-251. https://doi.org/10.2307/1169960.

Dansk, J. H. \& Kurcz, I. (1984). A comparison of reading comprehension processes in Polish and English. International Journal of Psychology, 19, 245-269.

Ellis, M. \& Niesobska, M. (2015). Program nauczania języka angielskiego. Kurs kontynuacyjny dla klas 1-3 gimnazjum. Poziom III.1 na podbudowie lletapu edukacyjnego [Teaching English syllabus. A continuation course for Year 1-3 of junior high school. III. 1 level, based on $2^{\text {nd }}$ stage of education]. Warszawa: Oxford University Press.

Ellis, R. (1985). Understanding second language acquisition. Oxford: Oxford University Press.

Farukh, A. \& Vulchanova, M. (2016). L1, quantity of exposure to L2 and reading disability as factors in L2 oral comprehension and production skills. Learning and Individual Differences, 50, 221-233.

Fromkin, V., Rodman, R. \& Hyams, N. (2011). An introduction to language. Wadsworth: Cengage Learning.

Ganschow, L. \& Sparks, R. L. (2000). Reflections on foreign language study for students with language learning problems: research, issues and challenges. Dyslexia, 6 (2), 87-100.

Geva, E. \& Verhoeven, L. (2000). Introduction: the development of second language reading in primary childrenresearch issues and trends. Scientific Studies of Reading, 4 (4), 261-266. 
Gál, É. \& Orbán, R. (2013). The relationship between the first language phonological awareness and the second language reading ability and the cross-language transfer of the first language phonological skills. Transylvanian Journal of Psychology, 14 (2), 173-193.

Główny Urząd Statystyczny. Departament Badań Demograficznych i Rynku Pracy (2015). Struktura narodowoetniczna, językowa i wyznaniowa ludności Polski. Narodowy Spis Powszechny Ludności i Mieszkań. [Nationalethnic, language, and denominational structure of Polish population. National Census of Population and Housing]. Warszawa: Główny Urząd Statystyczny.

Helland, T. \& Kaasa, R. (2005). Dyslexia in English as a second language. Dyslexia, 11 (1), 41-60.

Hoien, T. \& Lundberg, I. (2013). Dyslexia: from theory to intervention, ser. Neuropsychology and Cognition. Springer Netherlands.

Hoien, T., Lundberg, I., Stanovich, K. E. \& Bjaalid, I. (1995). Components of phonological awareness. Reading and Writing, 7 (2), 171-188.

ICD-10 (2000). Międzynarodowa Statystyczna Klasyfikacja Chorób i Problemów Zdrowotnych. Rewizja dziesiąta. Klasyfikacja zaburzeń psychicznych i zaburzeń zachowania w ICD-10. Opisy kliniczne i wskazówki diagnostyczne. [The ICD-10 Classification of Mental and Behavioural Disorders: Clinical Description and Diagnostic Guidelines]. Kraków-Warszawa: Vesalius.

Jaworowska, A., Matczak, A. \& Stańczak, J. (2010). Diagnoza dysleksji. Aneks do przewodnika diagnostycznego. Normalizacja dla uczniów klasy $V$ szkoły podstawowej. [Dyslexia assessment. Annex to the assessment manual. Normalisation for Year V elementary school students]. Warszawa: Pracownia Testów Psychologicznych Polskiego Towarzystwa Psychologicznego.

Jurek, A. (2004). Trudności w nauce języków obcych uczniów z dysleksją rozwojową [Foreign language learning difficulties of students with developmental dyslexia]. In M. Bogdanowicz \& M. Smoleń (Eds.), Dysleksja w kontekście nauczania języków obcych [Dyslexia in the context of foreign language instruction (pp. 98-116]. Gdańsk: Wydawnictwo „Harmonia”.

Kormos, J., Kiddle, T. \& Csizér, K. (2011). Systems of goals, attitudes, and self-related beliefs in second-languagelearning motivation. Applied Linguistics, 32 (5), 495-516.

Krasowicz-Kupis, G. (2006). Dysleksja a rozwój mowy ijęzyka [Dyslexia and the development of speech and language]. In G. Krasowicz-Kupis (Ed.), Dysleksja Rozwojowa. Perspektywa Psychologiczna [Developmental dyslexia. A psychological perspective (pp. 53-69)]. Gdansk: Wydawnictwo „Harmonia”.

Krasowicz-Kupis, G. (2008). Psychologia dysleksji [The psychology of dyslexia]. Warszawa: PWN.

Kubiak, B. (2003). Dwu - iwielojęzyczność dzieci [Bi- and multilingualism in children]. Języki Obce w Szkole, 6 (241), 39-49.

Lindgren, S. \& Laine, M. (2011). Multilingual dyslexia in university students: reading and writing patterns in three languages. Clinical Linguistics and Phonetics, 25 (9), 753-766.

Lyon Reid, G., Shaywitz, S. E. \& Shaywitz, B. A. (2003). A definition of dyslexia. Defining dyslexia, comorbidity, teachers' knowledge of language and reading. Annals of Dyslexia, 53, 1-14.

Łockiewicz, M., Jaskulska, M. (2015). Mental Lexicon, Working Memory, and L2 (English) Vocabulary in Polish Students with and without Dyslexia,CEPS Journal. 5 (1),71-90.

Łockiewicz, M., Jaskulska, M. (2016) Difficulties of Polish students with dyslexia in reading and spelling in English as L2. Learning and Individual Differences, 51. 256-264. https://doi.org/10.1016/j.lindif.2016.08.037.

Łockiewicz, M., Jaskulska, M. (2019). NL reading skills mediate the relationship between NL phonological processing skills and a foreign language (FL) reading skills in students with and without dyslexia: a case of a NL (Polish) and FL (English) with different degrees of orthographic consistency. Annals of Dyslexia, 69. $219-242$. https://doi.org/10.1007/s11881-019-00181-x.

Łockiewicz, M., Jaskulska, M. (2018). Umiejętności poprawnego zapisu wyrazów w L1 pośredniczą w związku pomiędzy poziomem przetwarzania fonologicznegow L1 a poprawnym zapisem wyrazów w L2 umłodzieży poprawnie czytającej, ale nie u młodzieży z dysleksją [L1 spelling mediates the relationship between the L1 phonological processing skills and L2 spelling in adolescents without, but not in adolescentswith dyslexia]. Edukacja, 2. 101-113. https://doi.org/10.24131/3724.180207.

Makarewicz, R. (2007). Problemy ukształtowania tekstu w pracach pisemnych uczniów dyslektycznych[Problems of text formation in the essays of dyslexic students]. In M. Kostka-Szymańska \& G. Krasowicz-Kupis (Eds.), Dysleksja. Problem znany czy nieznany? [Dyslexia. A problem known or unknown? (pp. 109-125)]. Lublin: Wydawnictwo Uniwersytetu Marii Curie-Skłodowskiej.

Mather, N. \& Wendling, B. J. (2012). Essentials of dyslexia assessment and intervention. Essentials of Psychological Assessment Series. Hoboken, New Jersey: John Wiley and Sons, Inc.

Milewski, T. (2006). Językoznawstwo [Linguistics]. Warszawa: PWN.

Nijakowska, J. (2010). Dyslexia in the Foreign Language Classroom. Bristol: St. Nicholas House. 
Nijakowska, J. (2016). Nauczyciel języka obcego wobec specyficznych trudności w uczeniu się [Teacher of a foreignlanguage and specific learning difficulties]. Języki Obce w Szkole, 4, 32-38.

Odlin, T. (1989). Language transfer: cross-linguistic influence in language learning. Cambridge: Cambridge University Press.

Palladino, P., Bellagamba, I., Ferrari, M. \& Cornoldi, C. (2013). Italian children with dyslexia are also poor in reading English words, but accurate in reading English pseudowords. Dyslexia, 19 (3), 165-177.

Paradowski, M. B. (2006). Uczyć, aby nauczyć - rola języka ojczystego w gramatyce pedagogicznej i implikacje dla dydaktyki języków obcych [Effective teaching - the role of mother tongue in educational grammar and implications for foreign languages didactics]. In J. Krieger-Knieja \& U. Paprocka-Piotrowska (Eds.), Komunikacja językowa w społeczeństwie informacyjnym - nowe wyzwania dla dydaktyki języków obcych [Linguistic communication in information society - new challenges for foreign language didactics, (pp. 125-144)]. Lublin: Towarzystwo Naukowe KUL.

Raven, J. C. (1991). Test Matryc. Wersja Standard. Seria a, B, C, D, E. [Progressive Matrices Test. Standard Version]. Warszawa: Pracownia Testów Psychologicznych Polskiego Towarzystwa Psychologicznego.

Ryndak, L. (2014). The International and Slavonic Phonetic Alphabets. Beyond Philology. An International Journal of Linguistics, Literary Studies and English Language Teaching, 11, 83-98.

Snowling, M. J. (2000). Dyslexia. Oxford: Blackwell Publishers.

Sparks, R. L., Patton, J., Ganschow, L., Humbach, N. \& Javorsky, J. (2006). Native language predictors of foreign language proficiency and foreign language aptitude. Annals of Dyslexia, 56 (1), 129-160.

Sparks, R. L., Patton, J., Ganschow, L. \& Humbach, N. (2009). Long-term crosslinguistic transfer of skills from I1 to 12. Language Learning, 59 (1), 203-243.

Sparks, R. L., Patton, J. \& Ganschow, L. (1993). The impact of native language learning problems on foreign language learning: case study illustrations of the linguistic coding deficit hypothesis. The Modern Language Journal, 77 (1), 58-74.

van Setten, E. R. H., Tops, W., Hakvoort, B. E. , van der Leij, A., Maurits, N. M. \& Maassen, B. A. M. (2017). L1 and L2 reading skills in Dutch adolescents with a familial risk of dyslexia. PeerJ, 5:e3895 https://doi.org/10.7717/peerj.3895

Wodniecka, Z., Mieszkowska, K., Durlik, J. \& Haman, E. (2018). Kiedy $1+1 \neq 2$, czyli jak dwujęzyczni przyswajają i przetwarzają język(i) [When $1+1 \neq 2$, or how bilinguals acquire and process language(s)]. In E. Czaplewska (Ed.), Logopedia międzykulturowa [Intercultural speech therapy (pp. 92-131)]. Gdańsk: Harmonia Universalis.

Zybert, J. (1999). Errors in foreign language learning: the case of Polish learners of English. Warszawa: Instytut Anglistyki Uniwersytetu Warszawskiego.

This work was supported by the University of Gdansk, under Grant no. 538-7416-B128-13. 